\title{
Plio-Pleistocene climatic change had a major impact on the assembly and disassembly processes of Iberian rodent communities
}

\author{
Manuel Hernández Fernández ${ }^{1,2}$ • Juan L. Cantalapiedra ${ }^{3,4}$ • Ana R. Gómez Cano ${ }^{5}$
}

Received: 18 November 2014 / Accepted: 15 April 2015 /Published online: 21 May 2015

(C) Senckenberg Gesellschaft für Naturforschung and Springer-Verlag Berlin Heidelberg 2015

\begin{abstract}
Comprehension of changes in community composition through multiple spatio-temporal scales is a prime challenge in ecology and palaeobiology. However, assembly, structuring and disassembly of biotic metacommunities in deep-time is insufficiently known. To address this, we used the extensively sampled Iberian Plio-Pleistocene fossil record of rodent faunas as our model system to explore how global climatic events may alter metacommunity structure. Through factor analysis, we found five sets of genera, called faunal components, which co-vary in proportional diversity over time. These faunal components had different spatio-temporal distributions throughout the Plio-Pleistocene, resulting in non-random changes in species assemblages, particularly in response to the development of the Pleistocene glaciations. Three successive metacommunities with distinctive taxonomic structures
\end{abstract}

This article is a contribution to the special issue "Old worlds, new ideas. A tribute to Albert van der Meulen".

Manuel Hernández Fernández

hdezfdez@ucm.es

1 Departamento de Paleontología, Facultad de Ciencias Geológicas, Universidad Complutense de Madrid (UCM), José Antonio Novais 2, 28040 Madrid, Spain

2 Departamento de Cambio Medioambiental, Instituto de Geociencias (UCM, CSIC), José Antonio Novais 2, 28040 Madrid, Spain

3 Departamento de Paleobiología. Museo Nacional de Ciencias Naturales, Consejo Superior de Investigaciones Científicas (CSIC), C. José Gutiérrez Abascal 2, 28006 Madrid, Spain

4 Museum für Naturkunde, Leibniz Institute for Evolution and Biodiversity Science, Invalidenstr 43, Berlin 10115, Germany

5 Institut de Génomique Fonctionnelle de Lyon, Université de Lyon, Université Lyon 1, Centre National de la Recherche Scientifique (CNRS), Ecole Normale Supérieure de Lyon, 46, allée d'Italie, Lyon cedex 07, 69364 Lyon, France were identified as a consequence of the differential responses of their members to global climatic change: (1) Ruscinian subtropical faunas (5.3-3.4 Ma) dominated by a faunal component that can be considered as a Miocene legacy; (2) transition faunas during the Villafranchian-Biharian (3.4-0.8 Ma) with a mixture of different faunal components; and (3) final dominance of the temperate Toringian faunas $(0.8-0.01 \mathrm{Ma})$ that would lead to the modern Iberian assemblage. The influence of the cooling global temperature drove the reorganisation of these rodent metacommunities. Selective extinction processes due to this large-scale environmental disturbance progressively eliminated the subtropical specialist species from the early Pliocene metacommunity. This disassembly process was accompanied by the organisation of a diversified metacommunity with an increased importance of biome generalist species, and finally followed by the assembly during the middle-late Pleistocene of a new set of species specialised in the novel environments developed as a consequence of the glaciations.

Keywords Community ecology · Global climatic change · Macroevolution · Mammalia · Metacommunity structure · Palaeoecology

\section{Introduction}

Understanding the processes behind the assembly (Diamond 1975) and the structure of modern (Brown et al. 2000; Millien-Parra and Loreau 2000; Gotelli and McCabe 2002; Feeley 2003; Morris 2005; Pennington et al. 2006; Emerson and Gillespie 2008; Ernest et al. 2008; Stegen and Swenson 2009; Abu Baker and Patterson 2010; Pavoine and Bonsall 2011; Belmaker and Jetz 2012; HilleRisLambers et al. 2012; Beaudrot et al. 2013; Cantalapiedra et al. 2014) and past (Riddle 1998; Costeur et al. 2004; Davis 2005; McGill et al. 2005; 
Van der Meulen et al. 2005; van Dam et al. 2006; Rodríguez 2006; Maridet et al. 2007; Casanovas-Vilar et al. 2010; Furió et al. 2011; Gómez Cano et al. 2013, 2014; Domingo et al. 2014; Martin and Peláez-Campomanes 2014) biological communities persists as a fundamental goal of ecology after decades of intense scrutiny. However, community ecology remains contentious and incompletely understood (Lawton 1999; Simberloff 2004; Ricklefs 2008; Leaper et al. 2013) especially regarding assembly processes spanning large temporal scales. Likewise, although community disassembly (Mikkelson 1993; Lomolino and Perault 2000) has received increased attention in the past several years (e.g. Thibault and Brown 2008; Okie and Brown 2009; Zavaleta et al. 2009; Leavitt and Fitzgerald 2013), its study over evolutionary time scales is much less advanced (but see Van der Meulen et al. 2005). Community disassembly over deep-time can be defined as a process of successive species losses, which are a reflection of progressive habitat change usually provoked by global climatic change. An understanding of ecological disassembly at an evolutionary scale may have important implications for conservation, because of the potential effects arising from the current anthropogenic global warming. In fact, based on the idea that faunal communities and metacommunities are non-random sets of species (Wilson 1999) and that palaeosynecological characterisation of past assemblages (Nieto and Rodríguez 2003; Costeur et al. 2013; García Yelo et al. 2014) enable the understanding of the processes involved in the development of their changing patterns through time, the fossil record has provided solid evidence of the link between abiotic factors, such as climate change, tectonics, etc., and biotic responses, such as speciation, extinction, dispersals, replacement, etc. (Vrba 1985; Barnosky 2001; van Dam et al. 2006; Benton 2009). Additionally, since processes operating at a hierarchy of spatial and temporal scales are thought to determine species sorting and potential source pools for assemblages (Preston 1960; Delcourt and Delcourt 1988; Brown and Maurer 1989; Wiens 1989; Levin 1992; Holt 1993; Ricklefs and Schluter 1993; Kelt 1999; Maurer 1999; Patterson 1999; Allen and Holling 2002; Ricklefs 2004; Emerson and Gillespie 2008; Smith et al. 2008; Pavoine and Bonsall 2011; Rull 2012), a greater understanding of community assembly and disassembly may be realised by complementing studies of modern biotic communities with studies of the deep-time distribution of species, thereby placing ecological processes within an evolutionary context.

The metacommunity concept has emerged as an important way to link multiple scales of spatio-temporal organisation in biological assemblages (Leibold et al. 2004). The recent interest in metacommunities has promoted a substantial advance in the comprehension of their functional dynamics (e.g. variations in species composition, turnover) in relation to external factors such as environmental gradients, landscape structure, disturbance regimes, habitat fragmentation or island area (e.g.
Leibold and Mikkelson 2002; Horváth et al. 2011; Stevens and Tello 2012; de la Sancha 2014). Nevertheless, a deeptime historical approach based on the understanding of the longterm changes observed in the fossil record (e.g. Van der Meulen and Daams 1992; Jaeger 1994; Daams et al. 1999; Badgley et al. 2008; Escarguel et al. 2008; Figueirido et al. 2012; Maridet et al. 2013; Gómez Cano et al. 2014) is also required in order to fully connect community ecology and evolutionary biology.

A metacommunity can be defined as a set of local communities that are linked by the dispersal of multiple potentially interacting species (Wilson 1992). Application of this concept to deep-time scales enables the analysis of their long-term dynamics, ranging from thousands to millions of years, which includes not only dispersal but also speciation and extinction of taxa within metacommunities. Within the palaeontological context, metacommunities allow for the integration of species from local faunas (registered in fossil sites) within a larger ecological entity, which mitigates the effects of various sources of local singularities (Escarguel et al. 2011), including sampling biases, spatio-temporal averaging of fossil sites, and differences due to environmental change or ecological succession in time or space. While contemporaneous local faunas share taxa through dispersal, the temporal dimension provided by the palaeontological record represents the interaction between faunal dynamics and progressive environmental changes in time and space. Therefore, this concept links directly with Olson's (1952) chronofauna: a geographically restricted natural assemblage of interacting animal populations through time, under the influence of changing environmental conditions, that has maintained its basic structure over a geologically significant period of time (Eronen 2007).

Although the distribution of species changes along environmental gradients, coherence of metacommunities depends on the consistent influence of the same environmental gradients on the ranges of a majority of its taxa (Presley et al. 2010). If this is not the case, distributions will not form a coherent structure (Leibold and Mikkelson 2002). Therefore, in order to search for such coherence across long time intervals, we focus on the identification of different sets of taxa with similar patterns in biodiversity change through time. Such differential behaviour should be related to contrasting responses to environmental shifts, which affect the ecological structure of palaeocommunities (Alroy et al. 2000; Barnosky 2005; Blois and Hadly 2009). Interestingly, recent analytical methods applied to high-resolution palaeontological data provide a powerful assessment of the succession across metacommunities of different biotic components sharing ecological affinities (Gómez Cano et al. 2014).

The quality and density of the vertebrate fossil record in the Iberian Peninsula (Sesé 2006) offers the opportunity to evaluate mammalian evolution and the long-term changes in their metacommunities in a fluctuating environment. The last major global revolution of climate was the transition from the 
Pliocene to the Pleistocene, ca. 2.7 Ma, which was marked by the development of successive Northern Hemisphere glaciations and which triggered major reorganisation in mammalian assemblages. Therefore, this paper focuses on the response of Iberian Plio-Pleistocene rodent metacommunities to climate change. Specifically, the goals of our study were: (1) to establish whether Iberian Plio-Pleistocene rodent taxa can be grouped according to similar diversity patterns through time as a result of similar ecological affinities; (2) to identify the influence of global climatic changes on the evolutionary dynamics of such groups; (3) to differentiate the structure of successive rodent metacomunities in relation to the relative importance of these groups; and (4) to assess the processes of disassembly and subsequent assembly of such metacommunities over a 5-Myr time interval spanning a major climatic event, the development of the Pleistocene northern glaciations.

\section{Materials and methods}

\section{Database}

The present research used the faunal lists of Plio-Pleistocene rodent communities in 43 fossil sites from the Iberian Peninsula, which have been subject to intensive sampling during the last 50 years (see references in Hernández Fernández et al. 2004). The biochronological framework for this work is based in the time calibration provided by Hernández Fernández et al. (2004). We are aware that new fossil sites have been reported and much progress in biochronology has been made since the construction of our database (e.g. García-Alix et al. 2009; Cuenca-Bescós et al. 2010a; Minwer-Barakat et al. 2012), and are currently in the progress of updating. Unfortunately, our new database was not yet available for the current analyses. Nevertheless, we are confident that the main conclusions of this work will not change significantly by additional information or marginal changes in dating of some fossil sites.

Since previous studies have shown that biogeographic context may have a major role in the interpretation of patterns of faunal change due to diachrony of biotic events among different bioprovinces (Gómez Cano et al. 2014), we have limited our study to the southern biogeographic province within the Iberoccitanian Subregion, as defined by Gómez Cano et al. (2011). This bioprovince includes most of the Neogene sedimentary basins from the Iberian Peninsula, excepting the Vallès-Penedès Basin, and is a very suitable area for the development of macroecological studies from a deep-time perspective due to the quantitative and qualitative importance of its fossil record (Sesé 2006). Additionally, due to its isolated position in the westernmost part of Europe, besides being currently recognised as an independent biogeographical unit within the Mediterranean Region (Heikinheimo et al. 2007), the study area exhibits unique environmental attributes since the Eocene, such as substantially higher aridity than in other bioprovinces from western Europe (Peláez-Campomanes 1993; Jiménez-Moreno and Suc 2007; Badiola et al. 2009; Furió et al. 2011).

The species lists for each fossil site were based upon a reviewed compilation from the literature and updated to the latest taxonomy. The minimum sample size required to include a fossil site in our study was 100 molars (including first and second upper and lower molars), which is considered to be the minimum number necessary to achieve a representative sample of the original assemblage, according to the relationship between species richness and sampling effort in small mammal fossil assemblages (van de Weerd and Daams 1978; Van der Meulen and Daams 1992; Daams et al. 1999). The taxonomic structure of mammalian faunas is generally considered to be informative on ecology because, due to shared inheritance of aspects of habitat-specifity, supraspecific taxa are to some extent restricted to specific adaptive zones and their species have relatively similar ecological niches, exhibiting clear patterns of change in community composition over evolutionary time (Andrews et al. 1979; Greenacre and Vrba 1984; Dodd and Stanton 1990; de Bonis et al. 1992; Van der Meulen and Daams 1992; Reed 1998; Hernández Fernández and Vrba 2006; Okie and Brown 2009). Therefore, we employed this dataset of rodent species to compile a matrix with information on the percentage of species of each genus in each fossil site. We used species percentages (relative richness) rather than number of species to avoid the potential influence of species richness on the results (Hernández Fernández and Vrba 2006), which can be affected by sampling biases (Casanovas-Vilar et al. 2014). Finally, our database consists of 408 records of 36 rodent genera in 43 fossil sites (Table 1).

\section{Identification of faunal components}

We applied Principal Component Analyses (PCA) to a sites/ genera (species percentage) matrix, and classified rodent genera into groups with similar patterns in the variation of species co-occurrence in time and space, which Gómez Cano et al. (2014) called faunal components. The PCA enabled us to portray the changes in the taxonomic structure of these rodent faunas (de Bonis et al. 1992; Van der Meulen and Daams 1992; Hernández Fernández and Vrba 2006) by reducing the number of original variables (36 genera) to a series of linear combinations among them (PCA factors). To maximize the sum of the within-factor variances, we used a VARIMAX rotated PCA model. The aim of this additional rotation was to obtain a simple structure in which the coefficients within a factor are as close to 1 or 0 as possible (Jackson 2003).

In order to establish the faunal components, we followed the methodology developed by Gómez Cano et al. (2014). We 


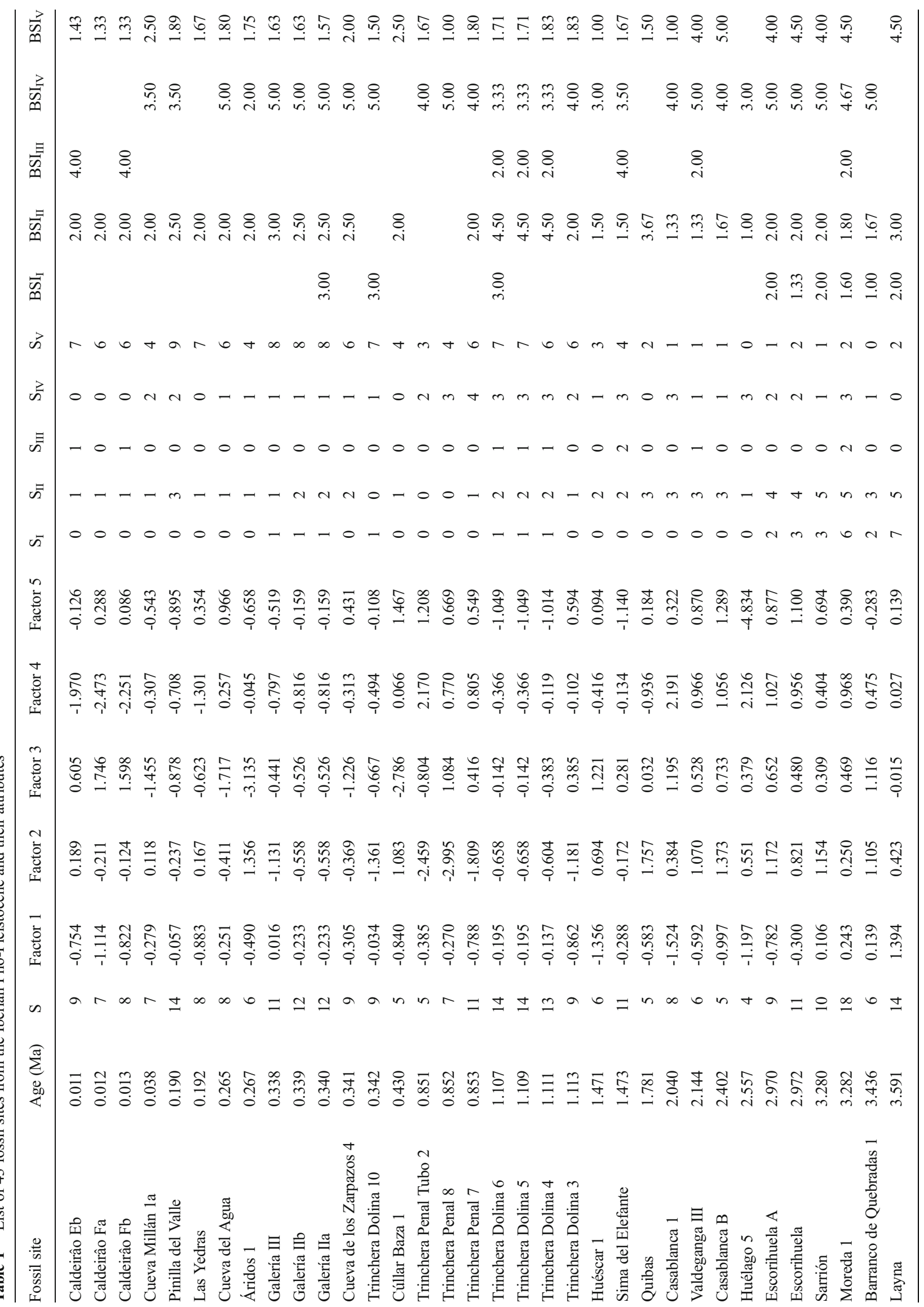


selected for each faunal component the genera that provide their highest contribution to a given factor. Thus, each genus belongs to only one faunal component based on the factor that includes the highest loading for this genus in the escalated components matrix, which shows the relationship among variables (genera) and the different factors independently of the dimensions of the latter. Subsequently, we evaluated the species richness (number of species in each genus) for the genera comprising each faunal component. Raw diversity patterns can provide complementary insights for the interpretation of the changes in community structure. We assumed that the common pattern over time and space shown by genera included in each faunal component, as reflected by co-variation among fossil sites, results from common ecological affinities and similar responses to ecological shifts.

We also studied the ecological characteristics of the species included in each faunal component by means of the Biomic Specialisation Index (BSI), developed by Hernández Fernández and Vrba (2005). This index indicates the degree of ecological specialisation of each species in terms of the number of biomes it inhabits. Therefore, BSI equals 1 for most specialised species whereas generalist species can exhibit a BSI as high as 10 . The data on the biome residence for all rodent species were obtained from Hernández Fernández et al. (2007), who inferred biome residences from identifying their living ecological analogues as estimated by ecomorphological studies of the dentition (Daams and Van der Meulen 1984; Hernández Fernández and Peláez-Campomanes 2003). For each faunal component, we calculated the relative frequency of specialist and generalist species in each fossil site in terms of the average value of the BSI of the species included in the corresponding faunal component. Following Gómez Cano et al. (2013), we only analysed taxa that were determined at the species level in each fossil site to avoid potential noise in the data due to unidentified taxa.

Analyses

We plotted the PCA factor scores, faunal-component richness and average BSI of each fossil site against time and applied a local regression-fitting procedure (LOESS) over the data to visualise their trend through time. This kind of representation reduces the influence of extreme data, which makes it appropriate for trend interpretation. We chose the smoothness of the fitted LOESS $(\lambda)$ using generalised cross-validation (GCV) to avoid overfitting the observed data (Kohn et al. 2000).

We evaluated the potential relationship between global climate changes and the temporal trends in rodent community structure by testing the correlation between the PCA factor scores, the richness of each faunal component or their average BSI at the fossil sites, and the global oxygen isotopic value $\left(\delta^{18} \mathrm{O}\right)$ associated with each locality as a proxy for palaeotemperature. In order to perform this analysis, we fitted a 
smoothed curve to the isotopic information (Zachos et al. 2008) and interpolated an isotopic value for the age of each fossil site. Although the $\delta^{18} \mathrm{O}$ values of Zachos et al. (2008) derive from global data on marine foraminifera and may not depict the temperature history for any particular place on land, they provide a general proxy for large climatic trends. For example, they are correlated with palaeotemperatures derived from the Iberian rodent fossil record (Hernández Fernández et al. 2007).

Since it is a commonly invoked model of community disassembly (Okie and Brown 2009), we assessed the presence of a nested structure in the assembly and disassembly patterns observed in the Iberian rodent metacommunities during the Plio-Pleistocene. This model proposes that communities within disturbed systems exhibit nested structure such that the taxa included in smaller communities represent a confined subset of those in richer assemblages, rather than a random selection of those found in the entire species pool (Patterson and Atmar 1986; Feeley 2003; Ulrich et al. 2009). This pattern would imply that each taxon requires some minimal conditions to support population levels adequate to resist extinction, and that it can occur in all sites that attain these conditions. We calculated the nestedness of the Plio-Pleistocene rodent assemblages of the Iberian Peninsula with the algorithm of Rodríguez-Gironés and Santamaría (2006) on genus presence-absence matrices ordered by genus richness and number of occurrences. This algorithm calculates the nested subset temperature (a nestedness score) of each matrix in such a way that the lower the score, the more nested the structure of the community (Atmar and Patterson 1993). We calculated $p$ values by means of a comparison to the distribution of scores generated by randomly shuffling the original matrices through 10,000 Monte Carlo simulations (row and sum totals were maintained constant). Nestedness analyses were run using the nestedness function as implemented in the R library BIPARTITE (R Development Core team 2014) and the null model 3 as suggested by Rodríguez-Gironés and Santamaría (2006), which is a constrained null model that accounts for the incidences of genera (column totals) and richnesses of fossil sites (row totals) while sampling the null space uniformly, which minimises type I and II errors. However, model 3 is a conservative test of nestedness, because type II errors may occur under particular circumstances around the generating constraints of the system under investigation (Patterson and Atmar 1986; Rodríguez-Gironés and Santamaría 2006; Frick et al. 2009). Finally, we compared the order in which assemblages were nested to their rank order based on richness, age and isotopic value using Spearman's rank correlation (Lomolino 1996; Patterson and Atmar 2000). These analyses were performed using the matrix of all Iberian PlioPleistocene rodent genera as well as using five independent matrices corresponding to the genera included in each faunal component. Therefore, we obtained six independent nested subset temperatures, derived from each one of these matrices, which indicate the level of nestedness in the whole rodent fauna as well as within each of the different faunal components.

\section{Results and discussion}

\section{Faunal components}

The factor analysis produced five significant factors (Table 2) which accounted for more than $80 \%$ of the variance. Thus, the Iberian Plio-Pleistocene rodent fossil record can be summarised in five sets of genera with similar patterns of variation within communities (Table 2), in the present paper called faunal components (FC I-V; Table 3). In order to clarify the differentiation between factors and faunal components, the former were numbered with Arabic notation and the latter with Roman numerals.

Faunal components are not composed of members of a single rodent family (which are usually interpreted as functional groups; see van Dam and Weltje 1999). Rather, each faunal component has members of a number of different families, performing different functions in the system. For example, FC I includes, among others, Pliopetaurista, a gliding squirrel associated with the upper canopy of dense woodlands and forests (Mein 1970; Hernández Fernández et al. 2007; García-Alix et al. 2008), the dormouse Muscardinus associated with lower canopy levels and the understorey of forest areas (Van der Meulen and De Bruijn 1982; Daams and Van der Meulen 1984; Mitchell-Jones et al. 1999; García-Alix et al. 2008; Daxner-Höck and Höck 2009; Prieto et al. 2014), the hamster Blancomys, probably an inhabitant of open environments (Hernández Fernández and PeláezCampomanes 2003; García-Alix et al. 2008), and the aquatic beaver Dipoides. In association with these divergences in habitat and spatial distribution, dietary or behavioural (diurnal vs. nocturnal) differences would suppose additional divisions of the eco-space occupied by the faunal components. In this way, each faunal component comprises groups of complementary, rather than similar, taxa. Although from these data we do not have the evidence to support it, we suggest that each faunal component may be a functioning system by itself, which integrates a set of functional groups, or guilds, that face environmental changes in a similar way. Interestingly, there are statistically significant differences among the mean BSI of the rodent species included in the genera assigned to different faunal components (Fig. 1). FC IV showed a significantly larger incidence of generalist species than FC I, FC II and FC V, which presented lower values of mean BSI (more biome-restricted taxa). FC III showed non-significant intermediate values between these two groups of faunal components, which is probably related to the few species in this component.

The temporal series of the five factors and the species diversity and average BSI of their related faunal components in each fossil site are represented in Fig. 2. 
Table 2 Results of the factor analysis on the structure of PlioPleistocene rodent faunas from the Iberian Peninsula

\begin{tabular}{|c|c|c|c|c|c|c|c|}
\hline & & & \multicolumn{5}{|l|}{ Factor } \\
\hline & & & 1 & 2 & 3 & 4 & 5 \\
\hline \multicolumn{3}{|l|}{ Eigenvalue } & 577.5 & 151.1 & 70.0 & 59.2 & 36.8 \\
\hline \multicolumn{3}{|c|}{$\%$ of total variance explained } & 53.6 & 14.0 & 6.6 & 5.5 & 3.4 \\
\hline \multicolumn{3}{|c|}{ Cumulative $\%$} & 53.6 & 67.7 & 74.2 & 79.7 & 83.1 \\
\hline Family & Subfamily & Genus & \multicolumn{5}{|c|}{ Rotated and rescaled component matrix } \\
\hline \multirow[t]{5}{*}{ Sciuridae } & Sciurinae & Pliopetaurista & 0.367 & 0.024 & 0.024 & 0.028 & -0.047 \\
\hline & & Sciurus & 0.119 & 0.145 & -0.037 & -0.009 & 0.017 \\
\hline & Xerinae & Atlantoxerus & 0.646 & 0.132 & 0.162 & 0.026 & 0.058 \\
\hline & & Marmota & -0.060 & -0.365 & -0.188 & -0.243 & -0.234 \\
\hline & & Spermophilinus & 0.248 & 0.074 & 0.035 & -0.018 & -0.026 \\
\hline \multirow[t]{3}{*}{ Gliridae } & Glirinae & Glis & -0.019 & -0.003 & 0.076 & 0.062 & -0.122 \\
\hline & Leithiinae & Eliomys & -0.387 & 0.737 & 0.007 & -0.055 & 0.431 \\
\hline & & Muscardinus & 0.275 & 0.021 & 0.059 & 0.079 & 0.046 \\
\hline \multirow[t]{2}{*}{ Castoridae } & Castorinae & Castor & -0.177 & 0.100 & -0.319 & 0.167 & -0.814 \\
\hline & Castoroidinae & Dipoides & 0.344 & -0.108 & 0.001 & 0.048 & 0.010 \\
\hline \multirow[t]{15}{*}{ Cricetidae } & Arvicolinae & Arvicola & -0.248 & 0.019 & -0.799 & -0.307 & 0.065 \\
\hline & & Chionomys & -0.176 & 0.005 & 0.252 & -0.473 & -0.003 \\
\hline & & Dolomys & 0.218 & 0.066 & -0.002 & 0.004 & 0.022 \\
\hline & & Microtus & -0.511 & -0.506 & -0.046 & -0.692 & $-\mathbf{0 . 0 3 0}$ \\
\hline & & Mimomys & -0.455 & 0.058 & 0.369 & 0.754 & -0.257 \\
\hline & & Clethrionomys & -0.039 & -0.075 & -0.304 & -0.020 & 0.062 \\
\hline & & Pliomys & -0.213 & -0.840 & -0.203 & 0.124 & 0.073 \\
\hline & & Promimomys & 0.250 & 0.012 & 0.000 & 0.021 & 0.050 \\
\hline & & Ungaromys & -0.045 & -0.027 & 0.044 & -0.021 & -0.178 \\
\hline & Cricetinae & Allocricetus & -0.297 & -0.363 & -0.750 & -0.015 & 0.149 \\
\hline & & Apocricetus & 0.700 & 0.038 & 0.057 & 0.024 & -0.031 \\
\hline & "Microtoid" & Blancomys & 0.336 & 0.335 & 0.265 & 0.226 & 0.115 \\
\hline & & Celadensia & 0.344 & -0.108 & 0.001 & 0.048 & 0.010 \\
\hline & & Ruscinomys & 0.826 & 0.095 & 0.112 & 0.059 & 0.019 \\
\hline & & Trilophomys & 0.438 & 0.330 & 0.220 & 0.176 & 0.172 \\
\hline \multirow[t]{10}{*}{ Muridae } & Gerbillinae & Debruijnimys & 0.250 & 0.012 & 0.000 & 0.021 & 0.050 \\
\hline & & Protatera & 0.371 & 0.095 & 0.062 & -0.028 & -0.035 \\
\hline & Murinae & Apodemus & -0.047 & 0.139 & -0.157 & 0.062 & 0.654 \\
\hline & & Castillomys & -0.058 & 0.627 & 0.436 & 0.439 & -0.190 \\
\hline & & Huerzelerimys & 0.250 & 0.012 & 0.000 & 0.021 & 0.050 \\
\hline & & "Micromys"a & 0.042 & -0.004 & 0.046 & 0.126 & -0.039 \\
\hline & & Occitanomys & 0.839 & 0.175 & 0.168 & 0.101 & 0.052 \\
\hline & & Paraethomys & 0.790 & 0.213 & 0.210 & 0.058 & 0.002 \\
\hline & & Rhagapodemus & 0.465 & -0.010 & 0.030 & 0.105 & 0.067 \\
\hline & & Stephanomys & 0.344 & 0.499 & 0.407 & 0.453 & 0.291 \\
\hline \multicolumn{2}{|l|}{ Hystricidae } & Hystrix & -0.033 & 0.015 & -0.190 & -0.285 & -0.137 \\
\hline
\end{tabular}

The rotated and rescaled component matrix obtained after factor analysis is shown, displaying each variable's loading on each factor. The values obtained are informative about the covariations among the variables (genera in this case) and establish the basis to group them, making reduction of the number of variables possible. Bold font indicates the highest values for each genus, which was the basis for including each in a faunal component. Systematic classification follows Wilson and Reeder (2005) excepting Clethrionomys, which has been recently considered the valid name for red-backed voles (Tesakov et al. 2010)

${ }^{a}$ Horáček et al. (2013) have proposed that the European Neogene-Quaternary Micromys species should be transferred to the genus Parapodemus 
Table 3 Genera included in each faunal component based upon their highest contribution to the factors derived from the factor analysis on the structure of PlioPleistocene rodent faunas from the Iberian Peninsula, according to the components matrix in Table 2

\begin{tabular}{|c|c|c|c|c|c|}
\hline \multirow[t]{2}{*}{ Family } & \multicolumn{5}{|l|}{ Faunal component } \\
\hline & I & II & III & IV & $\mathrm{V}$ \\
\hline Sciuridae & $\begin{array}{l}\text { Pliopetaurista } \\
\text { Atlantoxerus } \\
\text { Marmota } \\
\text { Spermophillinus }\end{array}$ & Sciurus & & & \\
\hline Gliridae & Muscardinus & Eliomys & Glis & & \\
\hline Castoridae & Dipoides & & & Castor & \\
\hline Cricetidae & $\begin{array}{l}\text { Dolomys } \\
\text { Promimomys } \\
\text { Apocricetus } \\
\text { Blancomys } \\
\text { Celadensia } \\
\text { Ruscinomys } \\
\text { Trilophomys }\end{array}$ & & $\begin{array}{l}\text { Chionomys } \\
\text { Ungaromys }\end{array}$ & $\begin{array}{l}\text { Mimomys } \\
\text { Pliomys }\end{array}$ & $\begin{array}{l}\text { Arvicola } \\
\text { Microtus } \\
\text { Clethrionomys } \\
\text { Allocricetus }\end{array}$ \\
\hline Muridae & $\begin{array}{l}\text { Debruijnimys } \\
\text { Protatera } \\
\text { Huerzelerimys } \\
\text { Occitanomys } \\
\text { Paraethomys } \\
\text { Rhagapodemus }\end{array}$ & $\begin{array}{l}\text { Castillomys } \\
\text { Stephanomys }\end{array}$ & "Micromys" & & Apodemus \\
\hline Hystricidae & & Hystrix & & & \\
\hline
\end{tabular}

FC I, with 19 genera and 31 species, is the most diverse faunal component detected for the Iberian rodent faunas of the Plio-Pleistocene and it was predominant during the Ruscinian (early Pliocene, 5.3-3.4 Ma; Fig. 2). More than half of the

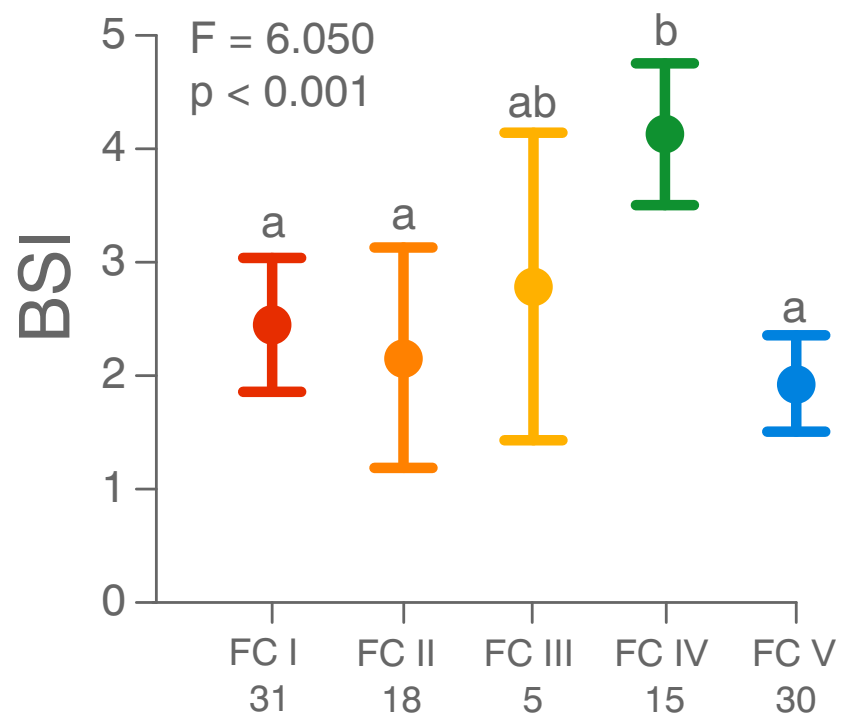

Fig. 1 Comparison of the mean biomic specialisation index (BSI) for each faunal component $(F C)$. $F$ and $p$ values from a one-way ANOVA for the 99 species studied are shown. Lower case letters indicate homogeneous subsets calculated by post hoc Tukey's test; mean BSI is significantly different among FCs when they do not share the same letter. Species numbers for each FC are shown below them genera included in this faunal component have also been recorded in the Miocene. Among these, murine genera are particularly diverse (Huerzelerimys, Paraethomys, Occitanomys and Rhagapodemus), as well as sciurids (Atlantoxerus, Spermophilinus, Pliopetaurista) and "microtoid" cricetines (Blancomys, Ruscinomys, Trilophomys). Genuine Pliocene taxa include some basal arvicolines (Promimomys and Dolomys), hypsodont cricetines (Celadensia) and gerbillines (Protatera).

Only two of the genera belonging to this faunal component remain in the modern faunas of Europe, Marmota and Muscardinus, associated with environments of the Eurosiberian Region (Mitchell-Jones et al. 1999), which are very different from the ecosystems of the Mediterranean Region (Peinado Lorca and Rivas-Martínez 1987). These genera, therefore, could currently be considered as relicts of the ancient Neogene faunas. Although Marmota is not recorded in Eurasia until the Pleistocene, its origin in North America during the middle Miocene (Savage and Russell 1983; Steppan et al. 1999; Goodwin 2008) associates this genus with the warm-adapted faunas that were widespread across the continent at that time (Potts and Behrensmeyer 1992; Figueirido et al. 2012). Such an origin might be related to the retention of similar ecological characteristics to those of Miocene and early Pliocene Old World native genera, which would subsequently have led to its inclusion within this faunal component. Moreover, modern Marmota monax, which is considered basal to the Eurasian marmots (Kruckenhauser et al. 1999; Steppan 

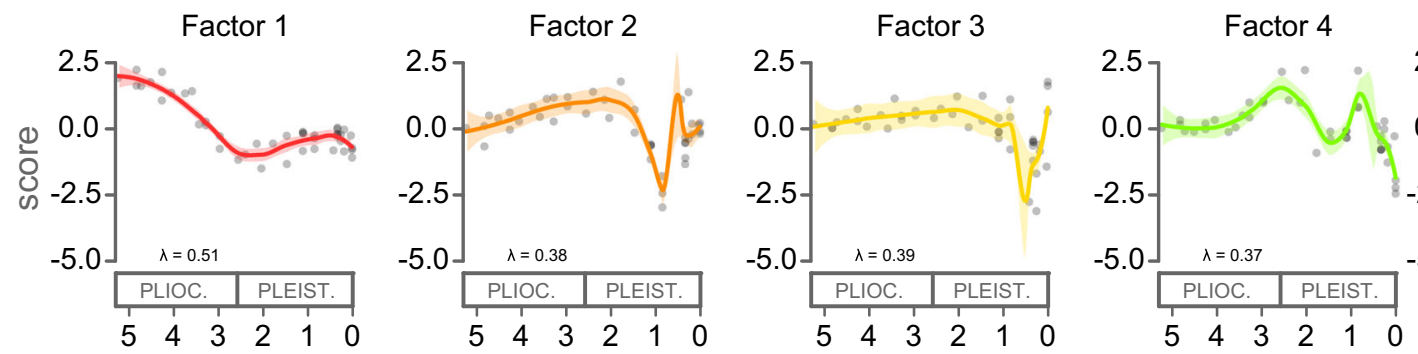

Factor 5
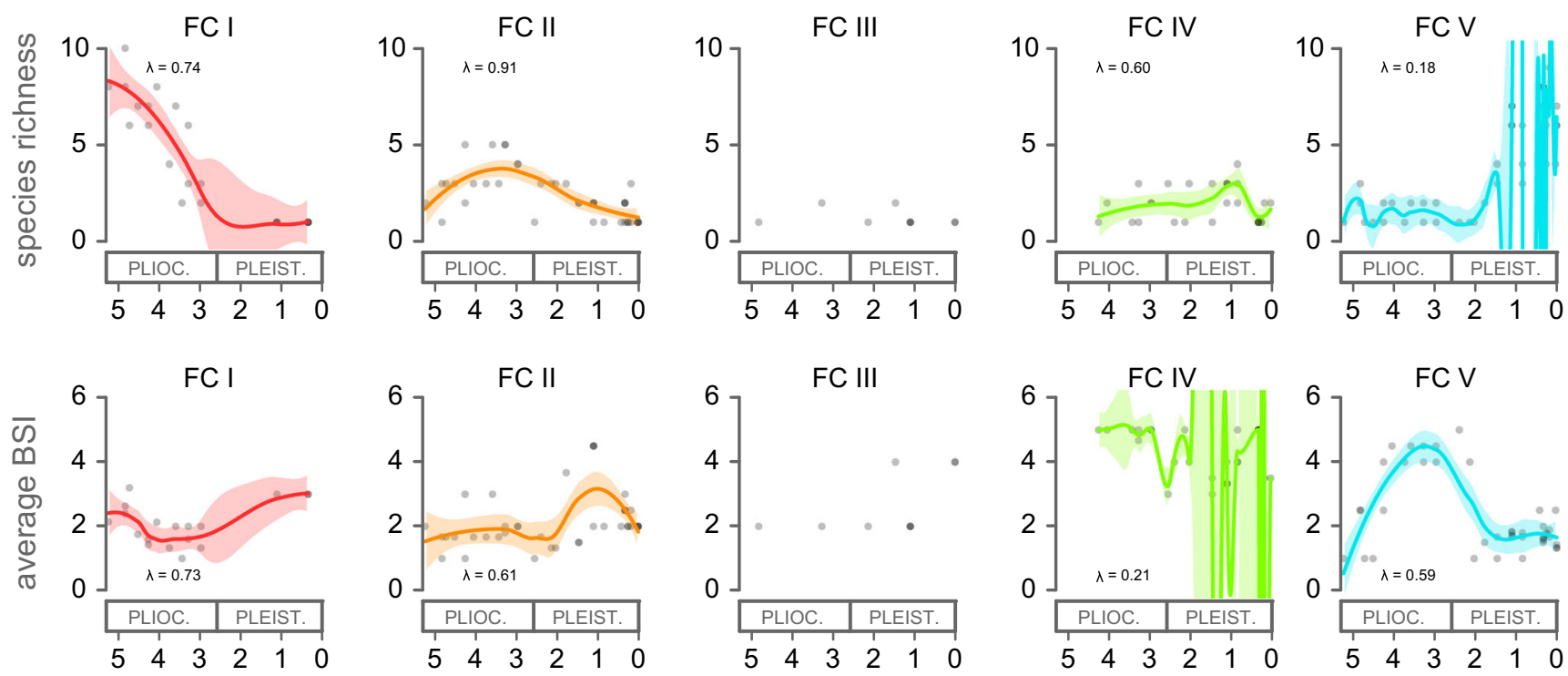

Fig. 2 Changes throughout time in the first five factors, variations in species richness for the genera included in each faunal component $(F C)$, and fluctuations in average biomic specialisation index $(B S I)$ for the species belonging to these genera, for all the Iberian rodent fossil sites analysed. To visualise trends throughout the Plio-Pleistocene, we applied

a local regression fitting (LOESS). The smoothing parameter $(\lambda)$ controls the balance between the goodness-of-fit of the model (see "Materials and methods"). Shaded areas represent the $95 \%$ confidence interval of the LOESS fit

Table 4 Results of the correlation analyses between the values of $\delta^{18} \mathrm{O}$ isotope (Zachos et al. 2008) and the factor scores, the species richness $\left(S_{i}, i\right.$ being the faunal components from $I$ to $V)$ or the average Biomic Specialisation Index (BSI, $i$ being the faunal components from $I$ to $V$ ) of each faunal component for the rodent fossil sites from the Iberian Plio-Pleistocene

\begin{tabular}{lrrr}
\hline & \multicolumn{1}{l}{ r } & \multicolumn{1}{l}{$p$} \\
\hline Factor 1 & -0.759 & $<0.001$ & 43 \\
Factor 2 & -0.371 & 0.014 & 43 \\
Factor 3 & -0.328 & 0.032 & 43 \\
Factor 4 & -0.330 & 0.031 & 43 \\
Factor 5 & -0.024 & 0.877 & 43 \\
S $_{\text {I }}$ & -0.865 & $<0.001$ & 43 \\
S $_{\text {II }}$ & -0.662 & $<0.001$ & 43 \\
S III $_{\text {IIV }}$ & 0.076 & 0.630 & 43 \\
S IV & 0.256 & 0.097 & 43 \\
S $_{\mathrm{V}}$ & 0.743 & $<0.001$ & 43 \\
BSI $_{\text {I }}$ & 0.554 & 0.017 & 18 \\
BSI $_{\text {II }}$ & 0.245 & 0.128 & 40 \\
BSI $_{\text {III }}$ & 0.625 & 0.072 & 9 \\
BSI IV & -0.388 & 0.037 & 29 \\
BSI IV & -0.466 & 0.002 & 41 \\
\hline
\end{tabular}

$r$ Pearson correlation coefficient; $p \mathrm{p}$ value; $n$ number of fossil sites analysed et al. 1999; Brandler and Lyapunova 2009), in addition to the northern taiga and temperate forests also inhabits relatively warm environments in southeastern North America. Nevertheless, since its contribution to factor 1 is very low (Table 2), Marmota should be regarded as an odd representative taxon of FC I.

Scores of factor 1 and species richness of FC I were negatively affected by global cooling (highly significant negative correlation between factor scores or species richness and $\delta^{18} \mathrm{O}$ values; Table 4). Additionally, although the average BSI of the species recorded in the Iberian fossil sites for this faunal component was fairly constant across the Plio-Pleistocene (Fig. 2), it experienced a significant increase in association with such global cooling (Table 4). FC I underwent a progressive demise concomitant with the Plio-Pleistocene global cooling trend and was succeeded by faunas adapted to cooler and more seasonal environments. Such decline has been related to the progressive extinction of species specialised for subtropical environments (Gómez Cano et al. 2013), which were not able to adapt to the new climatic conditions in the Iberian Peninsula (Hernández Fernández et al. 2007; Domingo et al. 2013).

FC II increased steadily during the Ruscinian and reached its highest richness during the middle Pliocene (Fig. 2), at the 
beginning of the Villafranchian (around 3.4 Ma). It has also a noteworthy composition of genera with representatives from the latest Miocene (Castillomys, Stephanomys, Eliomys and Hystrix), which could be considered related to cooler and more seasonal environments than the ones included in FC I (Hernández Fernández and Peláez-Campomanes 2003; García-Alix et al. 2008). This might be related to the temporal duration of the genera included in this faunal component, when compared with the ones in FC I; more than half of FC II genera remain in modern faunas, including Sciurus, Eliomys and Hystrix, two of them in the Iberian Peninsula.

Factor 2 and species richness of FC II were also negatively affected by the continued global cooling (significant negative correlation between them and $\delta^{18} \mathrm{O}$ values; Table 4). Although the average BSI of the species included in this faunal component changed little for the Pliocene fossil sites, it increased during the early Pleistocene, reaching its highest value around $1 \mathrm{Ma}$, before another decrease in the middle Pleistocene (Fig. 2). It seems that, after succeeding FC I during the middle and late Pliocene, continuous environmental cooling produced a preferential extinction of specialist species within this faunal component during the early Pleistocene and, finally, its collapse.

FC III appears to be a depauperate faunal component, with only four genera and five species registered in the Iberian PlioPleistocene (Table 3; Fig. 1), and mostly absent or with very low local species richness during the whole interval (Fig. 2). This component includes two genera of Miocene origin, such as the mouse "Micromys" and the dormouse Glis, as well as the Pleistocene voles Ungaromys and Chionomys. Taking into account the low local richness of this faunal component across Europe during the Plio-Pleistocene (Hernández Fernández 2001), and the geographical distribution of its representatives, which are for the most part limited to the Eurosiberian Region and mountain ranges of the Mediterranean Region (MitchellJones et al. 1999; Maul and Markova 2007; Horáček et al. 2013), a residual relevance of this faunal component in European rodent faunas might be advocated, particularly in central and southern Iberia. Only the biome generalist Chionomys nivalis still survives in the Mediterranean Region, taking advantage of the different woodless environments provided by mountain ranges, such as mountaintops above the tree-line, or sparsely covered prairies and rocky biotopes at lower altitudes (Mitchell-Jones et al. 1999; Purroy and Varela 2003).

As in the previous faunal components, the scores of factor 3 were negatively affected by global temperature cooling (significant negative correlation between these variables and $\delta^{18} \mathrm{O}$ values; Table 4). On the other hand, there was no significant relationship between the species richness or average BSI of FC III and $\delta^{18} \mathrm{O}$ values (Table 4 ), which is probably related to the low species numbers in this faunal component during the whole time interval studied here.

FC IV includes the Pliocene and early Pleistocene Mimomys, the recently extinct Pliomys (Chaline and Marquet
1976; Pokines 1998; Cuenca-Bescós et al. 2010b) and the modern genus Castor. The species richness of this faunal component was low during most of the time interval studied here (Fig. 2). It could be suggested that this faunal component in the Iberian Peninsula was peripheral in relation to European faunas, where it should be dominant during the middle-late Pliocene and early Pleistocene, according to the generally higher number of Mimomys species in fossil sites from northern, central and eastern Europe contemporaneous with the Iberian ones, such as Tegelen in The Netherlands (van Kolfschoten and Van der Meulen 1986; Tesakov 1998), Gundersheim 4 in Germany (Fejfar and Storch 1990), Osztramos 3 and Villány 5 in Hungary (Van der Meulen 1974; Janossy 1986), Rebielice Królewskie 1A, Kamyk, Kadzielnia 1 and Kielniki 3B in Poland (Nadachowski 1990, 1998) Uryv 1 and Tizdar 2 in Russia (Agadjanian 1976; Pevzner et al. 1998), or Tiligul, Zhevakhova Gora 5, Nogaisk and Luzanovka in Ucrania (Rekovets and Nadachowski 1995).

While scores of factor 4 were negatively affected by global cooling, the increase in proportion of specialist species of FC IV coincided with temperature decrease (significant negative correlation between $\delta^{18} \mathrm{O}$ values and PCA factor 4 scores or average BSI; Table 4). It seems that the Plio-Pleistocene global cooling is related to a progressive transition within this faunal component from biome generalist species to specialists in Iberia (Fig. 2), which could be interpreted as a progressive adaptation to new cooler environments. Nevertheless, the ratio between generalist and specialist species for the FC IV in central Iberian rodent faunas was strongly regulated by the glacial-interglacial cycles (Fig. 2), with a higher proportion of generalists during the interglacial phases and more specialists during the glacial ones, although the low species richness associated to this faunal component precludes a deeper analysis of this pattern. In any case, the final effect of the continuing Pleistocene glaciations was the complete substitution of the Mimomys associations of this faunal component by the modern Microtus-dominated faunas.

FC V includes Allocricetus and several modern taxa (Arvicola, Microtus, Clethrionomys, Apodemus), and is clearly dominant in the Iberian rodent faunas since the beginning of the middle Pleistocene (Fig. 2). Due to the high species richness of these five genera, which include 30 species, this faunal component marks a striking contrast with the diversity shown by FC I ( 31 species in 19 genera). It seems that the new ecosystems shaped by the development of the Pleistocene glaciations favoured a substantial increase in dominance of rodent faunas by only a few genera.

Although there was no significant relationship between the scores of factor 5 and $\delta^{18} \mathrm{O}$ values, species richness and the increase in proportion of specialist species of FC V were clearly favoured by the global cooling (highly significant positive correlation between $\mathrm{FC} \mathrm{V}$ richness and $\delta^{18} \mathrm{O}$ values, and significant negative correlation between its average BSI and 


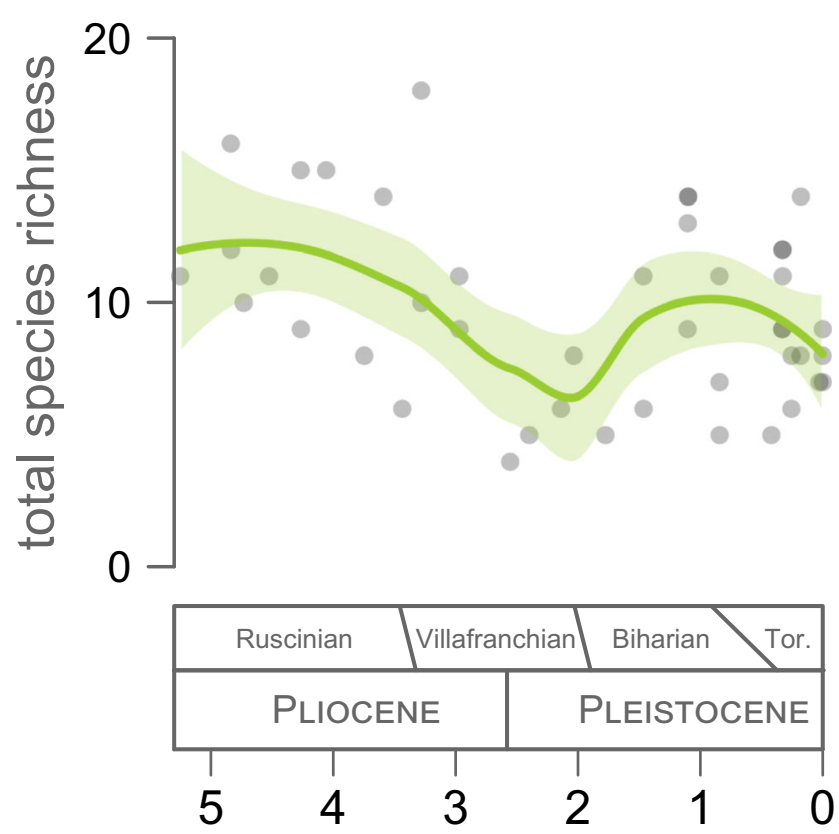

Fig. 3 Variation in rodent total richness for the Iberian fossil sites analysed. To visualise the general trend throughout the Plio-Pleistocene, we applied a local regression fitting (LOESS). The smoothing parameter ( $\lambda$ ) controls the balance between the goodness-of-fit of the model (see "Materials and methods"). The shaded area represents the $95 \%$ confidence interval of the LOESS fit

$\delta^{18} \mathrm{O}$ values; Table 4). The increase in species richness of this faunal component during the Pleistocene seems to reflect the diversification of a new set of species specialised for the novel environments associated with the development of the glaciations (Hernández Fernández et al. 2007; Gómez Cano et al. 2013). Particularly important in this context was the evolutionary radiation of Microtus voles (Chaline 1987; Chaline et al. 1999), which might be related to the surprisingly low statistical contribution of this genus to factor 5 (Table 2). Its explosive diversification into a plethora of new species in very different environments across the Holarctic realm could uncouple the development of Microtus (62 modern species, according to Wilson and Reeder 2005) from the other genera included in this faunal component, which maintained low to moderate diversification rates (Arvicola, 3 current species; Clethrionomys, 12 species; Apodemus, 20 species; Wilson and Reeder 2005). Finally, our analysis shows a significant oscillation of the richness in FC V since around $2 \mathrm{Ma}$. It appears that the richness increase within this faunal component during the Pleistocene was heavily influenced by the environmental changes associated with the glacialinterglacial cyclicity. This is probably related to geographical dispersion of northern species into the Mediterranean peninsulas, which acted as biotic refugia as a consequence of ice sheet advances in northern and central Europe (Blondel 2009), a phenomenon that has been identified by the occurrence of the so-called disharmonic faunas (Lundelius et al. 1987).
Metacommunity dynamics

Our analysis of the principal dynamic parameters of the rodent communities of the Iberian Peninsula revealed a process of faunal change across the Plio-Pleistocene with three main phases: (1) Ruscinian (early Pliocene, approximately 5.33.4 Ma) subtropical faunas dominated by FC I, which can be considered as a legacy from the Miocene; (2) transition faunas during the Villafranchian-Biharian (middle Pliocene-early Pleistocene, 3.4-0.8 Ma) with a mixture of different faunal components (FC II, FC IV and FC V); and (3) final dominance of the temperate Toringian (middle-late Pleistocene, 0.8 $0.01 \mathrm{Ma}$ ) faunas by FC V. Therefore, three distinctive metacommunity structures were identified as a consequence of the differential responses of their members to global climatic change. The statistically significant correlation between $\delta^{18} \mathrm{O}$ values and most of the faunal variables analysed (Table 4) indicates that the triggering of the faunal transition between successive metacommunities was directly or, most probably, indirectly linked to the global cooling that led to the Pleistocene glaciations.

Changes in total richness in the fossil sites analysed shows that the transitional phase is associated with the lowest richness values in the whole sequence (Fig. 3), which suggests that the beginning of the Pleistocene glaciations was a reset point for the Iberian rodent faunas. Although the total richness levels increased during the Pleistocene, there was a substantial change from the diversified Neogene assemblages to the Quaternary associations dominated by only a few genera, which appear to have strong responses to the glacial-interglacial cyclicity, particularly for FC V.

The proportion of specialist species in each faunal component suggests the operation of a species sorting mechanism related to ecological specialisation, with the triggering of the Pleistocene glaciations representing the main impetus for the development of a new metacommunity. Species sorting through habitat availability is likely to play a fundamental role in structuring metacommunities (Presley et al. 2012; Razafindratsima et al. 2013) because the evolutionary success of species is contingent on the presence of appropriate environmental conditions (Vrba 1987; Vrba 1992; Gómez Cano et al. 2013). This is corroborated by the results obtained in the nestedness analyses, which indicate that most of the matrices analysed show a significant nested pattern (Table 5) correlated to the variations in temperature (Table 6). Such a pattern suggests selective species loss associated to the existence of threshold requirements; certain species require particular environmental conditions to persist and thus are lost before other species that have less specialised requirements. This results in a nested structure.

Our results show that the disassembly of the Ruscinian rodent metacommunity from the Iberian Peninsula was a process of community change driven by non-random species losses, offering general insights into the impact of global 
Table 5 Results of analyses of nestedness for the Plio-Pleistocene rodent faunas from the Iberian Peninsula (Total) and for each faunal component $(F C)$

\begin{tabular}{lrll}
\hline & \multicolumn{1}{l}{ T } & Random T & \multicolumn{1}{l}{$p$} \\
\hline Total & 15.215 & 34.630 & $<0.01$ \\
FC I & 6.850 & 25.481 & $<0.01$ \\
FC II & 10.845 & 33.205 & $<0.01$ \\
FC III & 10.068 & 23.220 & 0.04 \\
FC IV & 29.782 & 39.020 & 0.15 \\
FC V & 0.342 & 28.980 & $<0.01$ \\
\hline
\end{tabular}

$T$ matrix temperature; random $T$ mean matrix temperature for 10,000 randomly shuffled matrices; $p p$ values based on the comparison between $\mathrm{T}$ and its distribution for 10,000 randomly shuffled matrices

climate change on the distributions of species and on the effects of environmental deterioration on species extinction. The Ruscinian rodent metacommunity showed an important contribution of the Miocene taxa included in FC I, which can be traced to the late Miocene rodent faunas of the Iberian Peninsula; indeed, it could be considered an extension of the late Miocene metacommunity described by Gómez Cano et al. (2014), which consisted mainly of two different faunal components. Notwithstanding, as a consequence of the continuous global cooling during the Pliocene, there was a preferential loss of species within FC I, while other faunal components were not affected or even temporarily expanded. The genus presence-absence matrix for FC I had a temperature nestedness score of 6.85 (Table 5), while for 10,000 randomly shuffled matrices the mean temperature was 34.63. Based on the distribution of nestedness scores for the null matrices, the probability that the observed matrix is more nested than random was highly significant $(p<0.01)$. The order in which FC I assemblages are nested is highly correlated to the rank order of isotopic value and age $(\rho=0.824, p<0.001$; and $\rho=0.978$, $p<0.001$, respectively; Table 6). Therefore, the environmental disturbance of the early Pliocene ecosystems derived from global cooling resulted in the non-random relaxation and breakdown of the original assemblages and formation of a different metacommunity.

Table 6 Results of the ranking correlation of Iberian PlioPleistocene rodent assemblages between their richness ranking and their age or isotopic ranking, for all the genera (Total) and for those included in each faunal component $(F C)$

\begin{tabular}{|c|c|c|c|c|c|c|c|}
\hline & & \multicolumn{6}{|c|}{ Genus richness ranking } \\
\hline & & Total & FC I & FC II & FC III & FC IV & FC V \\
\hline \multirow[t]{3}{*}{ Age ranking } & $\rho$ & 0.574 & 0.978 & 0.629 & 0.414 & -0.126 & -0.838 \\
\hline & $p$ & $<0.001$ & $<0.001$ & $<0.001$ & 0.268 & 0.515 & $<0.001$ \\
\hline & $\mathrm{N}$ & 43 & 22 & 40 & 9 & 29 & 41 \\
\hline \multirow[t]{3}{*}{ Isotopic ranking } & $\rho$ & 0.611 & 0.824 & 0.657 & 0.104 & -0.248 & -0.795 \\
\hline & $p$ & $<0.001$ & $<0.001$ & $<0.001$ & 0.791 & 0.194 & $<0.001$ \\
\hline & $\mathrm{N}$ & 43 & 22 & 40 & 9 & 29 & 41 \\
\hline
\end{tabular}

$\rho$ Spearman correlation coefficient
Villafranchian-Biharian assemblages constituted new nonrandom subsets of species, which differed significantly in their metacommunity structure from the Ruscinian ones. Dominance by FC I was replaced by an increase in the diversity of faunal components implied in the shaping of these middlelate Pliocene and early Pleistocene associations. This is probably related to the reorganisation of rodent assemblages and adaptation of their species to the growing influence of global cooling, which is supported by the increased importance of biome generalist species in these assemblages (Gómez Cano et al. 2013). Temperature nestedness scores for FC II, FC III and FC IV matrices were higher than for FC I (Table 5). In the case of the FC IV matrix, the observed nestedness pattern could not be differentiated from a random pattern. Finally, while FC II genus richness ranking is correlated with age and isotopic ranking, such is not the case for FC III and FC IV. It seems that this Villafranchian-Biharian metacommunity represented a transitional phase in the reorganisation of Iberian rodent faunas, in which its main faunal components showed a variable relationship with temperature change. Incorporation of multiple faunal components with lower levels of nestedness and limited or no relationship with temperature variations indicates a much lower structuration of the assemblages of this Villafranchian-Biharian metacommunity, which is probably related to the disturbance produced by strong environmental change in the transition from subtropical to temperate climates (Hernández Fernández et al. 2007).

Eventually, adaptation and specialisation into the new environments developed under the influence of the Pleistocene glaciations allowed the transformation into a new metacommunity with a distinct structure. The Toringian assemblages were strongly dominated by FC V in which only a few genera provided most of the species, with a higher degree of biome specialisation than observed in the previous metacommunity. The assemblages associated with this faunal component are highly nested (Table 5), and this non-random pattern is significantly correlated with isotopic and age ranking (Table 6), although in the opposite direction than for FC I. In this case, the incorporation of new genera to the Iberian 
communities, primarily through dispersion from central Europe but also due to in situ evolution, appears to be favoured by cooling during glacial stages. Nevertheless, FC V became dominant in the Iberian rodent faunas around $2 \mathrm{Ma}$ and, therefore, appears to be out of phase with the triggering of the glaciations around 2.7 Ma. This mismatch could be related to the time needed for the reorganisation of a new metacommunity with taxa that have evolved very recently.

The modern rodent metacommunities of the mediterranean environments from the Iberian Peninsula have been shaped through macroevolutionary processes that go back to the Miocene. A few long-ranging genera, which could be considered Miocene relicts (Sciurus, Eliomys), share the Iberian ecosystems with a new set of genera that have been favoured by the development of Pleistocene glaciations (Arvicola, Microtus, Apodemus), or at least have been able to survive them due to generalist habitat adaptation (Chionomys). Finally, commensalism of different species of Mus and Rattus with humans has led to the integration of new immigrant species within this assemblage during the Holocene (Morales Muñiz et al. 1995; Dobson 1998; Kowalski 2001; Ervynck 2002; Bonhomme et al. 2010; Valenzuela-Lamas et al. 2011).

Additionally, it is notable that there are some PlioPleistocene genera that are now absent from the Mediterranean Region of the Iberian Province but are still living in the Eurosiberian Region. These include Marmota, Glis, Muscardinus, Castor and Clethrionomys. The case for the inclusion of "Micromys" within this group of genera depends on the assignation of the Plio-Pleistocene species to Micromys as traditionally has been done, or to Parapodemus as suggested by Horáček et al. (2013). Interestingly, all these genera are allocated to almost any of the five faunal components described for the Iberian Plio-Pleistocene faunas. Therefore, it seems that environmental changes responsible for the loss of these taxa in Iberia might be multiple, in such a way that they could have an influence on varied faunal components.

\section{Final remarks}

Our results suggest that the Plio-Pleistocene fossil record of Iberian rodent assemblages includes groups of genera with ecological affinities, here called faunal components, with parallel waxing and waning patterns through time. These faunal components apparently were not dominated by members of a single functional group. Rather, each faunal component comprised members from a number of different functional groups (performing different functions in the system) such that the faunal component consisted of groups of complementary, rather than similar, taxa. We also found that, although they showed some overlap, these faunal components had differential distributions throughout the Plio-Pleistocene that resulted in non-random changes in the species assemblages, particularly in relation to the development of the Pleistocene glaciations. This large-scale environmental disturbance had striking consequences for the Iberian rodent assemblages, resulting in the disassembly of the Ruscinian rodent metacommunity and the subsequent assembly of two successive new metacommunities with distinctive structures. We conclude that the assembly processes involved in the development of these Iberian rodent metacommunities, driven by coincident changes in the surrounding palaeoenvironmental characteristics, resulted in the formation of highly structured assemblages of rodents in the modern Mediterranean woodlands and shrublands, as it is shown by its highly significant nested pattern.

A greater understanding of the patterns and processes of metacommunity assembly and disassembly will require assessment of larger temporal and spatial scales, spanning the Neogene-Quaternary and the multiple environmental changes through this time interval. It will also require taking into account the evolutionary shifts in species traits associated with membership in different functional groups. Finally, an additional and promising new line of research would include the phylogenetic relationships among the different taxa that characterise metacommunities through time. Explicit consideration of the interaction of all these processes should yield a greater insight into the assembly and dynamics of ecological communities at evolutionary scales.

This work demonstrates that incorporating deep-time perspectives offers considerable untapped potential for increasing our general understanding of community assembly and disassembly patterns caused by natural processes. Since similar disassembly processes may apply even though the changes in climate that occurred during the Neogene-Quaternary were much greater than the ones occurred so far in the current episode of global warming, studies based in the fossil record may hold important lessons for ecological consequences of anthropogenic changes and shed insights into conservation of mammalian communities in the increasingly disturbed ecosystems of the modern world.

Acknowledgements This paper is dedicated to Albert J. van der Meulen, leader in the field of mammalian palaeoecology and friend. Albert's works on Neogene rodent communities have been an inspiring force for anyone interested in community ecology and the influence of climatic changes on the evolution of mammal faunas. We want to thank the editors of this issue in his honour for their initiative and for inviting us to participate. We also acknowledge the insightful suggestions and comments on the manuscript made by Catherine Badgley (University of Michigan), Belén Luna (University of Castilla-La Mancha) and an anonymous reviewer, which greatly helped to improve this paper. This is a contribution by the Palaeoclimatology, Macroecology and Macroevolution of Vertebrates research team (www.pmmv.com.es) of the Complutense University of Madrid as a part of the Research Group UCM 910607 on Evolution of Cenozoic Mammals and Continental Palaeoenvironments. 


\section{References}

Abu Baker, M., \& Patterson, B. D. (2010). Patterns in the local assembly of Egyptian rodent faunas: areography and species combinations Mammalian. Mammalian Biology-Zeitschrift für Säugetierkunde, $75,510-522$.

Agadjanian, A. K. (1976). Voles (Microtinae, Rodentia) of Pliocene location Uryv I, the Middle Don. Proceedings of the Zoological Institute, Academy of Sciences of the USSR, 66, 58-97.

Allen, C. R., \& Holling, C. S. (2002). Cross-scale structure and scale breaks in ecosystems and other complex systems. Ecosystems, 5, 315-318.

Alroy, J., Koch, P. L., \& Zachos, J. C. (2000). Global climate change and North American mammalian evolution. Paleobiology, 26, 259-288.

Andrews, P., Lord, J. M., \& Evans, E. M. N. (1979). Patterns of ecological diversity in fossil and modern mammalian faunas. Biological Journal of the Linnean Society, 11, 177-205.

Atmar, W., \& Patterson, B. D. (1993). The measure of order and disorder in the distribution of species in fragmented habitat. Oecologia, 96, 373-382.

Badgley, C., Barry, J. C., Morgan, M. E., Nelson, S. V., Behrensmeyer, A. K., Cerling, T. E., et al. (2008). Ecological changes in Miocene mammalian record show impact of prolonged climatic forcing. Proceedings of the National Academy of Sciences of the USA, 105, 12145-12149.

Badiola, A., Checa, L., Cuesta, M. A., Quer, R., Hooker, J. I., \& Astibia, H. (2009). The role of new Iberian finds in understanding European Eocene mammalian palaeobiogeography. Geologica Acta, 7, 243258.

Barnosky, A. D. (2001). Distinguishing the effects of the Red Queen and Court Jester on Miocene mammal evolution in the northern Rocky Mountains. Journal of Vertebrate Paleontology, 21, 172-185.

Barnosky, A. D. (2005). Effects of quaternary climatic change on speciation in mammals. Journal of Mammalian Evolution, 12, 247-264.

Beaudrot, L., Struebig, M. J., Meijaard, E., Van Balen, S., Husson, S., Young, C. F., et al. (2013). Interspecific interactions between primates, birds, bats, and squirrels may affect community composition on Borneo. American Journal of Primatology, 75, 170-185.

Belmaker, J., \& Jetz, W. (2012). Regional pools and environmental controls of vertebrate richness. The American Naturalist, 179, 512-523.

Benton, M. J. (2009). The Red Queen and the Court Jester: species diversity and the role of biotic and abiotic factors through time. Science, 323, 728-732.

Blois, J. L., \& Hadly, E. A. (2009). Mammalian response to cenozoic climatic change. Annual Review of Earth and Planetary Sciences, $37,181-208$.

Blondel, J. (2009). The nature and origin of the vertebrate fauna. In J. Woodward (Ed.), The physical geography of the Mediterranean (pp. 139-163). Oxford: Oxford University Press.

Bonhomme, F., Orth, A., Cucchi, T., Rajabi-Maham, H., Catalan, J., Boursot, P., et al. (2010). Genetic differentiation of the house mouse around the Mediterranean basin: matrilineal footprints of early and late colonization. Proceedings of the Royal Society of London B, 278, rspb20101228.

Bonis, L. de, Bouvrain, G., Geeraads, D., \& Koufos, G. (1992). Multivariate study of late Cenozoic mammalian faunal compositions and paleoecology. Paleontologia i Evolució, 24, 25-93.

Brandler, O. V., \& Lyapunova, E. A. (2009). Molecular phylogenies of the genus Marmota (Rodentia Sciuridae): comparative analysis. Ethology Ecology and Evolution, 21, 289-298.

Brown, J. H., Fox, B. J., \& Kelt, D. A. (2000). Assembly rules: desert rodent communities are structured at scales from local to continental. The American Naturalist, 156, 314-321.
Brown, J. H., \& Maurer, B. A. (1989). Macroecology: the division of food and space among species on continents. Science, 243, 11451150 .

Cantalapiedra, J. L., Hernández Fernández, M., \& Morales, J. (2014). Biogeographic history of ruminant faunas determines the phylogenetic structure of their assemblages at different scales. Ecography, $37,1-9$.

Casanovas-Vilar, I., García-Paredes, I., Alba, D. M., Hoek Ostende, L. W. van den, \& Moyà-Solà, S. (2010). The European Far West: Miocene mammal isolation, diversity and turnover in the Iberian Peninsula. Journal of Biogeography, 37, 1079-1093.

Casanovas-Vilar, I., Hoek Ostende, L. W. van den, Furió, M., \& Madern, P. A. (2014). The range and extent of the Vallesian Crisis (Late Miocene): new prospects based on the micromammal record from the Vallès-Penedès basin (Catalonia, Spain). Journal of Iberian Geology, 40, 29-48.

Chaline, J. (1987). Arvicolid data (Arvicolidae, Rodentia) and evolutionary concepts. In M. K. Hecht (Ed.), Evolutionary Biology (pp. 237310). Berlin: Springer.

Chaline, J., Brunet-Lecomte, P., Montuire, S., Viriot, L., \& Courant, F. (1999). Anatomy of the arvicoline radiation (Rodentia): palaeogeographical, palaeoecological history and evolutionary data. Annales Zoologici Fennici, 36, 239-267.

Chaline, J., \& Marquet, J. C. (1976). Les conséquences stratigraphiques de la persistance en France dans le Würm ancien del rongeurs reliques Pliomys lenki et Allocricetus bursae (Rodentia). Comptes Rendus de l'Académie des Sciences de Paris D, 282, 1941-1942.

Costeur, L., Legendre, S., \& Escarguel, G. (2004). European large mammals palaeobiogeography and biodiversity during the Neogene. Palaeogeographic and climatic impacts. Revue de Paléobiologie, 9, 99-109.

Costeur, L., Maridet, O., Montuire, S., \& Legendre, S. (2013). Evidence of northern Turolian savannah-woodland from the Dorn-Dürkheim 1 fauna (Germany). In J. L. Franzen, \& M. Pickford (eds) DornDürkheim 1, Germany: A highly diverse Turolian fauna from midlatitude Europe. Palaeobiodiversity and Palaeoenvironments, 93(2), 259-275.

Cuenca-Bescós, G., Rofes, J., López-García, J. M., Blain, H.-A., De Marfá, R. J., Galindo-Pellicena, M. A., et al. (2010a). Biochronology of Spanish Quaternary small vertebrate faunas. Quaternary International, 212, 109-119.

Cuenca-Bescós, G., Straus, L. G., García-Pimienta, J. C., Morales, M. R., \& López-García, J. M. (2010b). Late Quaternary small mammal turnover in the Cantabrian Region: The extinction of Pliomys lenki (Rodentia, Mammalia). Quaternary International, 212, 129-136.

Daams, R., \& Meulen, A. J. van der (1984). Paleoenvironmental and paleoclimatic interpretation of micromammal faunal successions in the Upper Oligocene and Miocene of north central Spain. Paléobiologie Continentale, 14, 241-257.

Daams, R., Meulen, A. J. van der, Peláez-Campomanes, P., \& ÁlvarezSierra, M. A. (1999). Trends in rodent assemblages from the Aragonian (early-middle Miocene) of the Calatayud-Daroca Basin, Aragon, Spain. In J. Agustí, L. Rook, \& P. Andrews (Eds.), Hominoid evolution and climatic change in Europe (pp. 127-139). Cambridge: Cambridge University Press.

Dam, J. A. van, Abdul Aziz, H., Álvarez-Sierra, M. A., Hilgen, F. J., Hoek Ostende, L. W. van den, Lourens, L. J., et al. (2006). Longperiod astronomical forcing of mammal turnover. Nature, 443, 687691.

Dam, J. A. van, \& Weltje, G. J. (1999). Reconstruction of the Late Miocene climate of Spain using rodent palaeocommunity successions: an application of end-member modelling. Palaeogeography, Palaeoclimatology, Palaeoecology, 151, 267-305.

Davis, E. B. (2005). Mammalian beta diversity in the Great Basin, western USA: palaeontological data suggest deep origin of modern 
macroecological structure. Global Ecology and Biogeography, 14, 479-490.

Daxner-Höck, G., \& Höck, E. (2009). New data on Eomyidae and Gliridae (Rodentia, Mammalia) from the Late Miocene of Austria. Annalen des Naturhistorischen Museums in Wien, 111, 375-444.

de la Sancha, N. U. (2014). Patterns of small mammal diversity in fragments of subtropical Interior Atlantic Forest in eastern Paraguay. Mammalia, 78, 437-449.

Delcourt, H. R., \& Delcourt, P. A. (1988). Quaternary landscape ecology: relevant scales in space and time. Landscape Ecology, 2, 23-44.

Diamond, J. M. (1975). The island dilemma: lessons of modern biogeographic studies for the design of natural reserves. Biological Conservation, 7, 129-146.

Dobson, M. (1998). Mammal distributions in the western Mediterranean: the role of human intervention. Mammal Review, 28, 77-88.

Dodd, J. R., \& Stanton, R. J. (1990). Paleoecology: concepts and applications. New York: Wiley.

Domingo, L., Koch, P. L., Hernández Fernández, M., Fox, D. L., Domingo, M. S., \& Alberdi, M. T. (2013). Late Neogene and early Quaternary paleoenvironmental and paleoclimatic conditions in southwestern Europe: isotopic analyses on mammalian taxa. PloS ONE, 8, e63739.

Domingo, M. S., Badgley, C., Azanza, B., DeMiguel, D., \& Alberdi, M. T. (2014). Diversification of mammals from the Miocene of Spain. Paleobiology, 40, 197-221.

Emerson, B. C., \& Gillespie, R. G. (2008). Phylogenetic analysis of community assembly and structure over space and time. Trends in Ecology and Evolution, 23, 619-630.

Ernest, S. K. M., Brown, J. H., Thibault, K. M., White, E. P., \& Goheen, J. R. (2008). Zero sum, the niche, and metacommunities: long-term dynamics of community assembly. The American Naturalist, 172, E257-E269.

Eronen, J. T. (2007). Locality coverage, metacommunities and chronofauna: concepts that connect paleobiology to modern population biology. Vertebrata Palasiatica, 45, 137-144.

Ervynck, A. (2002). Sedentism or urbanism? On the origin of the commensal black rat (Rattus rattus). In K. Dobney \& T. P. O'Conner (Eds.), Bones and the man: studies in honour of Don Brothwell (pp. 95-109). Oxford: Oxbow.

Escarguel, G., Fara, E., Brayard, A., \& Legendre, S. (2011). Biodiversity is not (and never has been) a bed of roses! Comptes Rendus Biologies, 334, 351-359.

Escarguel, G., Legendre, S., \& Sigé, B. (2008). Unearthing deep-time biodiversity changes: the Palaeogene mammalian metacommunity of the Quercy and Limagne area (Massif Central, France). Comptes Rendus Geoscience, 340, 602-614.

Feeley, K. (2003). Analysis of avian communities in Lake Guri. Venezuela, using multiple assembly rule models. Oecologia, 137, 104-113.

Fejfar, O., \& Storch, G. (1990). Eine pliozäne (ober-ruscinische) Kleinsäugerfauna aus Gundersheim, Rheinhessen. 1. Nagetiere: Mammalia, Rodentia. Senckenbergiana lethaea, 71, 139-184.

Figueirido, B., Janis, C. M., Pérez-Claros, J. A., De Renzi, M., \& Palmqvist, P. (2012). Cenozoic climate change influences mammalian evolutionary dynamics. Proceedings of the National Academy of Sciences of the USA, 109, 722-727.

Frick, W. F., Hayes, J. P., \& Heady, P. A. (2009). Nestedness of desert bat assemblages: species composition patterns in insular and terrestrial landscapes. Oecologia, 158, 687-697.

Furió, M., Casanovas-Vilar, I., \& Hoek Ostende, L. W. van den (2011). Predictable structure of Miocene insectivore (Lipotyphla) faunas in Western Europe along a latitudinal gradient. Palaeogeography Palaeoclimatology Palaeoecology, 304, 219-229.

García-Alix, A., Minwer-Barakat, R., Martín-Suárez, E., Freudenthal, M., \& Martín, J. M. (2008). Late Miocene-Early Pliocene climatic evolution of the Granada Basin (southern Spain) deduced from the paleoecology of the micromammal associations. Palaeogeography Palaeoclimatology Palaeoecology, 265, 214-225.

García-Alix, A., Minwer-Barakat, R., Martín-Suárez, E., \& Freudenthal, M. (2009). Small mammal from the early Pleistocene of the Granada Basin, southern Spain). Quaternary Research, 72, 265-274.

García Yelo, B. A., Gómez Cano, A. R., Cantalapiedra, J. L., Alcalde, G. M., Sanisidro, O., Oliver, A., et al. (2014). Palaeoenvironmental analysis of the Aragonian (middle Miocene) mammalian faunas from the Madrid Basin based on body-size structure. Journal of Iberian Geology, 40, 129-140.

Gómez Cano, A. R., Hernández Fernández, M., \& Álvarez-Sierra, M. A. (2011). Biogeographic provincialism in rodent faunas from the Iberoccitanian Region (southwestern Europe) generates severe diachrony within the Mammalian Neogene (MN) biochronologic scale during the Late Miocene. Palaeogeography Palaeoclimatology Palaeoecology, 307, 193-204.

Gómez Cano, A. R., Cantalapiedra, J., Mesa, A., Moreno Bofarull, A., \& Hernandez Fernandez, M. (2013). Global climate changes drive ecological specialization of mammal faunas: trends in rodent assemblages from the Iberian Plio-Pleistocene. BMC Evolutionary Biology, 13, 94. doi:10.1186/1471-2148-13-94.

Gómez Cano, A. R., Cantalapiedra, J. L., Álvarez-Sierra, M. A., \& Hernández Fernández, M. (2014). A macroecological glance at the structure of late Miocene rodent assemblages from Southwest Europe. Scientific Reports, 4, 6557.

Goodwin, H. T. (2008). Sciuridae. In C. Janis, G. Gunnell, \& M. Uhen (Eds.), Evolution of Tertiary mammals of North America (Vol. 2, pp. 355-376). Cambridge: Cambridge University Press.

Gotelli, N. J., \& McCabe, D. J. (2002). Species co-occurrence: a metaanalysis of JM Diamond's assembly rules model. Ecology, 83, 2091-2096.

Greenacre, M. J., \& Vrba, E. S. (1984). Graphical display and interpretation of antelope census data in African wildlife areas, using correspondence analysis. Ecology, 65, 984-997.

Heikinheimo, H., Fortelius, M., Eronen, J. T., \& Mannila, H. (2007). Biogeography of European land mammals shows environmentally distinct and spatially coherent clusters. Journal of Biogeography, 34, 1053-1064.

Hernández Fernández, M. (2001). Análisis paleoclimático y paleoecológico de las sucesiones de mamíferos del PlioPleistoceno de la Península Ibérica. PhD Thesis, Universidad Complutense de Madrid, Madrid.

Hernández Fernández, M., \& Peláez-Campomanes, P. (2003). Ecomorphological characterization of Murinae and hypsodont "Cricetidae" (rodentia) from the Iberian Plio-Pleistocene. Coloquios de Paleontología, 1, 237-251.

Hernández Fernández, M., \& Vrba, E. S. (2005). Macroevolutionary processes and biomic specialization: testing the resource-use hypothesis. Evolutionary Ecology, 19, 199-219.

Hernández Fernández, M., \& Vrba, E. S. (2006). Plio-Pleistocene climatic change in the Turkana Basin (East Africa): evidence from large mammal faunas. Journal of Human Evolution, 50, 595-626.

Hernández Fernández, M., Azanza, B., \& Álvarez-Sierra, M. A. (2004). Iberian Plio-Pleistocene biochronology: micromammalian evidence for MNs and ELMAs calibration in southwestern Europe. Journal of Quaternary Science, 19, 605-616.

Hernández Fernández, M., Álvarez-Sierra, M. A., \& Peláez-Campomanes, P. (2007). Bioclimatic analysis of rodent palaeofaunas reveals severe climatic changes in Southwestern Europe during the Plio-Pleistocene. Palaeogeography Palaeoclimatology Palaeoecology, 251, 500 526.

HilleRisLambers, J., Adler, P. B., Harpole, W. S., Levine, J. M., \& Mayfield, M. M. (2012). Rethinking community assembly through the lens of coexistence theory. Annual Review of Ecology, Evolution, and Systematics, 43, 227-248. 
Holt, R. D. (1993). Ecology at the mesoscale: the influence of regional processes on local communities Species diversity in ecological communities. In R. Ricklefs \& D. Schluter (Eds.), Species diversity in ecological communities (pp. 77-88). Chicago: University of Chicago Press.

Horáček, I., Knitlová, M., Wagner, J., Kordos, L., \& Nadachowski, A. (2013). Late Cenozoic history of the genus Micromys (Mammalia, Rodentia) in Central Europe. PloS ONE, 8, e62498.

Horváth, G., Herczeg, R., Tamási, K., \& Sali, N. (2011). Nestedness of small mammal assemblages and role of indicator species in isolated marshland habitats. Natura Somogyiensis, 19, 281-283.

Jackson, J. E. (2003). A user's guide to Principal Components. New York: Wiley-Interscience.

Jaeger, J.-J. (1994). The evolution of biodiversity among the Southwest European Neogene rodent (Mammalia, Rodentia) communities: pattern and process of diversification and extinction. Palaeogeography Palaeoclimatology Palaeoecology, 111, 305-336.

Janossy, D. (1986). Pleistocene vertebrate faunas of Hungary. Budapest: Akadémiai Kiadó.

Jiménez-Moreno, G., \& Suc, J.-P. (2007). Middle Miocene latitudinal climatic gradient in Western Europe: evidence from pollen records. Palaeogeography Palaeoclimatology Palaeoecology, 253, 208225.

Kelt, D. A. (1999). On the relative importance of history and ecology in structuring communities of desert small animals. Ecography, 22, $123-137$.

Kohn, R., Schimek, M. G., \& Smith, M. (2000). Spline and kernel regression for dependent data. In M. G. Schimekk (Ed.), Smoothing and Regression: approaches, computation and application (pp. 135-158). New York: Wiley.

Kolfschoten, T. van, \& Meulen, A. J. van der (1986). Villanyian and Biharian mammal faunas from The Netherlands. Memoire della Societa Geologica Italiana, 31, 191-200.

Kowalski, K. (2001). Pleistocene rodents of Europe. Folia Quaternaria, 72, 3-389.

Kruckenhauser, L., Pinsker, W., Haring, E., \& Arnold, W. (1999). Marmot phylogeny revisited: molecular evidence for a diphyletic origin of sociality. Journal of Zoological Systematics and Evolutionary Research, 37, 49-56.

Lawton, J. H. (1999). Are there general laws in ecology? Oikos, 84, 177192.

Leaper, R., Dunstan, P. K., Foster, S. D., Barrett, N. S., \& Edgar, G. J. (2013). Do communities exist? Complex patterns of overlapping marine species distributions. Ecology, 95, 2016-2025.

Leavitt, D. J., \& Fitzgerald, L. A. (2013). Disassembly of a dune-dwelling lizard community due to landscape fragmentation. Ecosphere, 4, art97.

Leibold, M. A., Holyoak, M., Mouquet, N., Amarasekare, P., Chase, J. M., Hoopes, M. F., et al. (2004). The metacommunity concept: a framework for multi-scale community ecology. Ecology Letters, 7, 601-613.

Leibold, M. A., \& Mikkelson, G. M. (2002). Coherence, species turnover, and boundary clumping: elements of meta-community structure. Oikos, 97, 237-250.

Levin, S. A. (1992). The problem of pattern and scale in ecology. Ecology, 73, 1943-1967.

Lomolino, M. (1996). Investigating causality of nestedness of insular communities: selective immigrations or extinctions? Journal of Biogeography, 23, 699-703.

Lomolino, M. V., \& Perault, D. R. (2000). Assembly and disassembly of mammal communities in a fragmented temperate rain forest. Ecology, 81, 1517-1532.

Lundelius, E. L., Downs, T., Lindsay, E. H., Semken, H. A., Zakrzewski, R. J., Churcher, C. S., et al. (1987). The North American Quaternary sequence. In M. O. Woodburne (Ed.), Cenozoic mammals of North
America: geochronology and biostratigraphy (pp. 211-235). Berkeley: University of California Press.

Maridet, O., Escarguel, G., Costeur, L., Mein, P., Hugueney, M., \& Legendre, S. (2007). Small mammal (rodents and lagomorphs) European biogeography from the Late Oligocene to the mid Pliocene. Global Ecology and Biogeography, 16, 529-544.

Maridet, O., Costeur, L., \& Legendre, S. (2013). European Neogene rodent communities: explaining family-level replacements through a spatiotemporal approach. Historical Biology, 25, 655-677.

Martin, R. A., \& Peláez-Campomanes, P. (2014). Diversity dynamics of the Late Cenozoic rodent community from south-western Kansas: the influence of historical processes on community structure. Journal of Quaternary Science, 29, 221-231.

Maul, L. C., \& Markova, A. K. (2007). Similarity and regional differences in Quaternary arvicolid evolution in Central and Eastern Europe. Quaternary International, 160, 81-99.

Maurer, B. A. (1999). Untangling ecological complexity: the macroscopic perspective. Chicago: University of Chicago Press.

McGill, B. J., Hadly, E. A., \& Maurer, B. A. (2005). Community inertia of Quatrnary small mammal assemblages in North America. Proceedings of the National Academy of Sciences of the USA, 102, 16701-16706.

Mein, P. (1970). Les sciuroptères (Mammalia, Rodentia) néogènes d'Europe occidentale. Geobios, 3, 7-77.

Meulen, A. J. van der (1974). On Microtus (Allophaiomys) deucalion (Kretzoi, 1969), (Arvicolidae, Rodentia), from the upper Villányian (Lower Pleistocene) of Villány-5, S. Hungary. Proceedings of the Koninklijke Nederlandse Akademie van Wetenschappen, Ser. B, 77, 259-266.

Meulen, A. J. van der, \& Bruijn, H. de (1982). The mammals from the Lower Miocene of Aliveri (Island of Evia, Greece). Proceedings of the Koninklijke Nederlandse Akademie van Wetenschappen, Ser. B, $85,485-524$.

Meulen, A. J. van der, \& Daams, R. (1992). Evolution of Early-Middle Miocene rodent faunas in relation to long-term palaeoenvironmental changes. Palaeogeography Palaeoclimatology Palaeoecology, 93, 227-253.

Meulen, A. J. van der, Peláez-Campomanes, P., \& Levin, S. A. (2005). Age structure, residents, and transients of Miocene rodent communities. The American Naturalist, 165, E108-E125.

Mikkelson, G. M. (1993). How do food webs fall apart? A study of changes in trophic structure during relaxation on habitat fragments. Oikos, 67, 539-547.

Millien-Parra, V., \& Loreau, M. (2000). Community composition and size structure of murid rodents in relation to the biogeography of the Japanese archipelago. Ecography, 23, 413-423.

Minwer-Barakat, R., García-Alix, A., Martín Suárez, E., Freudenthal, M., \& Viseras, C. (2012). Micromammal biostratigraphy of the Upper Miocene to lowest Pleistocene continental deposits of the Guadix basin, southern Spain. Lethaia, 45, 594-614.

Mitchell-Jones, A. J., Amori, G., Bogdanowicz, W., Krystufek, B., Reijnders, P. J. H., Spitzenberger, F., et al. (1999). The Atlas of European Mammals. London: Academic.

Morales Muñiz, A., Cereijo Pecharroman, M. A., Hernández Carrasquilla, F., \& Liesau von Lettow-Vorbeck, C. (1995). Of mice and sparrows: commensal faunas from the Iberian Iron Age in the Duero Valley (Central Spain). International Journal of Osteoarchaeology, 5, 127138.

Morris, D. W. (2005). On the roles of time, space and habitat in a boreal small mammal assemblage: predictably stochastic assembly. Oikos, 109, 223-238.

Nadachowski, A. (1990). Lower Pleistocene rodents of Poland: faunal succession and biostratigraphy. Quartärpaläontologie, 8, 215-223.

Nadachowski, A. (1998). Faunal succession of small mammal assemblages at the Pliocene-Pleistocene boundary in Poland. Mededelingen 
Nederlands Instituut voor Toegepaste Geowetenschappen TNO, 60, 281-286.

Nieto, M., \& Rodríguez, J. (2003). Inferencia paleoecológica en mamíferos cenozoicos: limitaciones metodológicas. Coloquios de Paleontología, 1, 459-474.

Okie, J. G., \& Brown, J. H. (2009). Niches, body sizes, and the disassembly of mammal communities on the Sunda Shelf islands. Proceedings of the National Academy of Sciences of the USA, 106, 19679-19684.

Olson, E. C. (1952). The evolution of a Permian vertebrate chronofauna. Evolution, 6, 181-196.

Patterson, B. D. (1999). Contingency and determinism in mammalian biogeography: the role of history. Journal of Mammalogy, 80, 345-360.

Patterson, B. D., \& Atmar, W. (1986). Nested subsets and the structure of insular mammalian faunas and archipelagos Biological. Biological Journal of the Linnean Society, 28, 65-82.

Patterson, B. D., \& Atmar, W. (2000). Analyzing species composition in fragments. Bonner Zoologische Monographien, 46, 9-24.

Pavoine, S., \& Bonsall, M. B. (2011). Measuring biodiversity to explain community assembly: a unified approach. Biological Reviews, 86, $792-812$.

Peinado Lorca, M., \& Rivas-Martínez, S. (1987). La vegetación de España. Alcalá de Henares: Servicio de Publicaciones de la Universidad de Alcalá de Henares.

Peláez-Campomanes, P. (1993). Micromamíferos del Paleogeno Continental Español: Sistemática, Biocronología y Paleoecología. $\mathrm{PhD}$ thesis, Universidad Complutense de Madrid, Madrid.

Pennington, R. T., Richardson, J. E., \& Lavin, M. (2006). Insights into the historical construction of species-rich biomes from dated plant phylogenies, neutral ecological theory and phylogenetic community structure. New Phytologist, 172, 605-616.

Pevzner, M., Tesakov, A., \& Vangengeim, E. (1998). The position of the Tizdar locality (Taman Peninsula, Russia) in the magnetochronological scale. Paludicola, 2, 95-97.

Pokines, J. T. (1998). A late survival of Pliomys lenki (Heller, 1930) in Cantabrian Spain. Mammalia, 62, 143-145.

Potts, R., \& Behrensmeyer, A. K. (1992). Late Cenozoic terrestrial ecosystems. In A. K. Behrensmeyer, J. D. Damuth, W. A. DiMichele, R. Potts, H.-D. Sues, \& S. L. Wing (Eds.), Terrestrial ecosystems through time (pp. 419-541). Chicago: University of Chicago Press.

Presley, S. J., Cisneros, L. M., Patterson, B. D., \& Willig, M. R. (2012). Vertebrate metacommunity structure along an extensive elevational gradient in the tropics: a comparison of bats, rodents and birds. Global Ecology and Biogeography, 21, 968-976.

Presley, S. J., Higgins, C. L., \& Willig, M. R. (2010). A comprehensive framework for the evaluation of metacommunity structure. Oikos, 119, 908-917.

Preston, F. W. (1960). Time and space and the variation of species. Ecology, 41, 611-627.

Prieto, G., Angelone, C., Casanovas-Vilar, I., Gross, M., Hír, J., Hoek Ostende, L. W. van den, et al. (2014). The small mammals from Gratkorn: an overview. In M. Böhme, M. Gross, J. Prieto (eds) The Sarmatian vertebrate locality Gratkorn, Styrian Basin. Palaeobiodiversity and Palaeoenvironments, 94(1), 135-162.

Purroy, F. J., \& Varela, J. M. (2003). Guía de los mamíferos de España: Península, Baleares y Canarias. Barcelona: Lynx.

R Development Core team. (2014). R: A language and environment for statistical computing. Vienna: R Foundation for Statistical Computing.

Razafindratsima, O. H., Mehtani, S., \& Dunham, A. E. (2013). Extinctions, traits and phylogenetic community structure: insights from primate assemblages in Madagascar. Ecography, 36, 47-56.

Reed, K. E. (1998). Using large mammal communities to examine ecological and taxonomic structure and predict vegetation in extant and extinct assemblages. Paleobiology, 24, 384-408.
Rekovets, L., \& Nadachowski, A. (1995). Pleistocene voles (Arvicolidae) of the Ukraine. Paleontologia i Evolució, 28-29, 145-245.

Ricklefs, R. E. (2004). A comprehensive framework for global patterns in biodiversity. Ecology Letters, 7, 1-15.

Ricklefs, R. E. (2008). Disintegration of the ecological community. The American Naturalist, 172, 741-750.

Ricklefs, R. E., \& Schluter, D. (1993). Species diversity in ecological communities: historical and geographical perspectives. Chicago: University of Chicago Press.

Riddle, B. R. (1998). The historical assembly of continental biotas: late Quaternary range-shifting, areas of endemism, and bio-geographic structure in the North American mammal fauna. Ecography, 21, $437-442$.

Rodríguez, J. (2006). Structural continuity and multiple alternative stable States in Middle Pleistocene European mammalian communities. Palaeogeography Palaeoclimatology Palaeoecology, 239, 355373.

Rodríguez-Gironés, M. A., \& Santamaría, L. (2006). A new algorithm to calculate the nestedness temperature of presence-absence matrices. Journal of Biogeography, 33, 924-935.

Rull, V. (2012). Community ecology: diversity and dynamics over time. Community Ecology, 13, 102-116.

Savage, D. E., \& Russell, D. E. (1983). Mammalian paleofaunas of the world. Reading: Addison-Wesley.

Sesé, C. (2006). Los roedores y lagomorfos del Neógeno de España. Estudios Geológicos, 62, 429-480.

Simberloff, D. (2004). Community ecology: is it time to move on? The American Naturalist, 163, 787-799.

Smith, F. A., Lyons, S. K., Ernest, S. K. M., \& Brown, J. H. (2008). Macroecology: more than the division of food and space among species on continents. Progress in Physical Geography, 32, 115138.

Stegen, J. C., \& Swenson, N. G. (2009). Functional trait assembly through ecological and evolutionary time. Theoretical Ecology, 2, 239-250.

Steppan, S. J., Akhverdyan, M. R., Lyapunova, E. A., Fraser, D. G., Vorontsov, N. N., Hoffmann, R. S., et al. (1999). Molecular phylogeny of the marmots (Rodentia: Sciuridae): tests of evolutionary and biogeographic hypotheses. Systematic Biology, 48, $715-734$.

Stevens, R. D., \& Tello, J. S. (2012). Do desert rodents form metacommunities? Journal of Mammalogy, 93, 1029-1041.

Tesakov, A. S. (1998). Voles of the Tegelen fauna. Mededelingen Nederlands Instituut voor Toegepaste Geowetenschappen TNO, 60, 71-134.

Tesakov, A. S., Lebedev, V. S., Bannikova, A. A., \& Abramson, N. I. (2010). Clethrionomys Tilesius, 1850 is the valid generic name for red-backed voles and Myodes Pallas, 1811 is a junior synonym of Lemmus Link, 1795. Russian Journal of Theriology, 9, $83-86$.

Thibault, K. M., \& Brown, J. H. (2008). Impact of an extreme climatic event on community assembly. Proceedings of the National Academy of Sciences of the USA, 105, 3410-3415.

Ulrich, W., Almeida-Neto, M., \& Gotelli, N. (2009). A consumer's guide to nestedness analysis. Oikos, 118, 3-17.

Valenzuela-Lamas, S., Baylac, M., Cucchi, T., \& Vigne, J. D. (2011). House mouse dispersal in Iron Age Spain: a geometric morphometrics appraisal. Biological Journal of the Linnean Society, 102, 483497.

Vrba, E. S. (1985). Environment and evolution: alternative causes of the temporal distribution of evolutionary events. South African Journal of Science, 81, 229-236.

Vrba, E. S. (1987). Ecology in relation to speciation rates: some case histories of miocene-recent mammal clades. Evolutionary Ecology, 1, 283-300. 
Vrba, E. S. (1992). Mammals as a key to evolutionary theory. Journal of Mammalogy, 73, 1-28.

Weerd, A. van de, \& Daams, R. (1978). Quantitative composition of rodent faunas in the Spanish Neogene and paleoecological implications. I \& II. Proceedings of the Koninklijke Nederlandse Akademie van Wetenschappen, Ser. B, 81, 448473.

Wiens, J. A. (1989). Spatial scaling in ecology. Functional Ecology, 3, 385-397.

Wilson, D. E., \& Reeder, D. M. (2005). Mammal species of the world: a taxonomic and geographic reference. Baltimore: Johns Hopkins University Press.
Wilson, D. S. (1992). Complex interactions in metacommunities, with implications for biodiversity and higher levels of selection. Ecology, 73, 1984-2000.

Wilson, J. B. (1999). Guilds, functional types and ecological groups. Oikos, 86, 507-522.

Zachos, J. C., Dickens, G. R., \& Zeebe, R. E. (2008). An early Cenozoic perspective on greenhouse warming and carbon-cycle dynamics. Nature, 451, 279-283.

Zavaleta, E., Pasari, J., Moore, J., Hernandez, D., Suttle, K. B., \& Wilmers, C. C. (2009). Ecosystem responses to community disassembly. Annals of the New York Academy of Sciences, 1162, 311333. 